\title{
FROM ART TO THE EVERYDAY: ROBIN BOYD AND THE 'WINDOWWALL'
}

\author{
PHILIP GOAD \\ Faculty of Architecture, Building and Planning \\ University of Melbourne \\ VIC 3010, Australia
}

p.goad@unimelb.edu.au

\begin{abstract}
Throughout his career, Australian architect and critic Robin Boyd (1919-1971) explored alternatives for the orthodox elements of architecture. Using the laboratory-scale of the detached house, Boyd would rethink wall, roof, floor and window. He was interested in making such elements serve more than one function. He wanted to rationalise the architectural palette with the hope that his invented elements might develop new formal meaning, and hence potential acceptance at a broader professional and popular level. An early target of Boyd's design research was the combination of window and wall, culminating in 1952-53 with the patented Stegbar 'Windowall', a modular structural window framing system that was to have national application across the full breadth of Australian domestic architecture from the 1950s to the 1970s. Neil Clerehan has observed that, "It was with the Windowall that Boyd, more than any other single architect, gave our suburbs a distinctive look. Even Palladio couldn't do that. The Stegbar victory was his greatest triumph. His Windowalls were an intrinsic look of the fifties" (60).

This paper follows the development of Boyd's window-wall, from his earliest known projects in the late 1930s to unique custom-designed solutions, and in parallel the industrial application of his ideas that would give direction to his own project house designs, and subsequently influence the appearance of the typical suburban home. It will be shown that this process was one of transformation: in a characteristically modernist displacement, Boyd transformed the window of the artist's studio to become a structural glazed frame for the everyday Australian living room (Colquhoun 51).
\end{abstract}

Keywords: Australian architecture, modernism, Robin Boyd, windows.

\section{Introduction: the studio window}

In 1938, Robin Boyd, then 19 years old and a student at the Melbourne University Architectural Atelier (MUAA), designed and oversaw the construction of a painting studio for his cousin Arthur Boyd (1920-1999) in the back garden of the Boyds' house in Wahroonga Crescent, Murrumbeena in suburban Melbourne. A feature of the tiny single-storey structure, in which Boyd's cousin could not only paint but live, was the studio window: a canted bank of eight fixed glass panels. This window was not just a practical source of daylight. It was also a symbol of the 
idea of the artist's studio, the multi-functional light-filled volume that combined living with art. The Boyd studio was thus an echo, albeit a suburban one, not just of the mansard roof garrets of Melbourne's $19^{\text {th }}$ century artists in Collins Street but also of spaces like the light-filled studio designed for Amedée Ozenfant (1886-1966) in Paris (1922-23) by Le Corbusier and Pierre Jeanneret, and which Peter Serenyi and later Kenneth Frampton were to suggest appeared to cater for the 'spiritual needs of the 'artist/monk', as the new ideal, metropolitan man' (Serenyi, Frampton 43). A key feature of the Ozenfant studio was not just its industrial glazed studio windows but also its luminous ceiling lit by two saw-tooth roofs, an idea that would also find its echo in a later Boyd project.

A year later, Boyd's design for a skillion-roofed suburban house (1939), took the idea of the studio apartment as the basis for an ideal house type ("House"). The main window to the double-height living room was another 'studio-window', a large sixteen-panel structural frame infilled with glass. In the space of a year, Boyd had jumped to the scale of the everyday. He had produced a suburbanised Maison Citrohan, a studio as the home for everyman (Etchells).

\section{Studio window and glazed stud frame}

During World War II and whilst on active service in the Australian Army's Field Survey Corps, Boyd and Kevin Pethebridge's 1944 unplaced entry in the Sun Post-war Homes competition was evidence of a new direction for Boyd's design research on the postwar house (The Sun). A key feature of their design for an extendible house was the boxed studio window to the main living room, a memory of Serge Chermayeff's boxed studio window to the dining room of Bentley Wood, Halland, East Sussex (1938). However along the side of the Boyd and Pethebridge design, the windows to the bedrooms comprised structural timber mullions with glazing running up to the underside of the eaves, with fixed vision panels surmounted by banks of glazed louvres that provided ventilation at ceiling level. In this competition design, Boyd was examining the key component of domestic construction in Australia, the timber stud frame, and how it might be able to function not just as structure but also as a window frame. While there would have been local precedent in the modulated all-glass walls of Roy Grounds's Clendon flats, Malvern (1939-40) and Quamby flats, South Yarra (1940-41), it is almost certain that Boyd's interests in minimising architectural elements would have been encouraged by the pragmatic systems building techniques of his wartime experiences in Papua New Guinea (Goad and Willis).

By 1947, in the design of his own home in Riversdale Road, Camberwell, Boyd was to bring these two ideas - the studio window and the glazed stud frame - closer together. Facing a creek gully, the house's long east elevation was glazed by a canted studio window of twenty-four fixed and openable sashes that sloped down and outwards. The intention was to direct the view into the adjacent creek gully ("House near Melbourne", "House at Camberwell"). This giant screen was non-structural. Directly behind it, Boyd exposed the vertical stud frame. It was as if he was deliberately showing the window's role as a non-structural visor. To the one and a half height volume of the house's 'studio' living room, Boyd introduced a much larger floor-to-ceiling studio window as a glazed infill between two brick veneer walls. Boyd's private rumination on studio windows in his own home-laboratory was to be the preface to a very public preoccupation on the role of window joinery in the everyday house.

That same year, in July 1947 Robin Boyd became Director of the RVIA Small Homes Service, a housing bureau that promoted progressive domestic design ideas to the average homeowner, offering architect-designed house plans and specification for $£ 5.00$ as part of the profession's postwar effort in responsibly reducing the postwar housing shortage (Goad). Part of Boyd's role as Director was to write about these designs on a weekly basis in The Age newspaper. Thus between 1947 and 1953, Boyd would, on numerous occasions, extol the virtues of glazing between structural studwork and infilling with large fixed vision panels and glazed louvres, in effect asserting his thesis of the glazed studio window to the living room (now a full floor to ceiling glass wall) and a series of bedroom windows with glazing between studwork. Boyd was arguing for simplified window frames which an amateur carpenter could assemble on the job, thus reducing the cost of expensive shop joinery (Boyd).

\section{Turning to the sun}

At the same time and as a sole practitioner, Boyd extended his research on the completely glazed wall in one-off house designs for private clients. The Douglas Gillison house, Balwyn, Victoria (1950-51) was designed on a principal grid of 8' 6" (2590mm) timber posts ("The Life and Good Works"). Between these, glass was held in a wooden frame in which the light 
members were set diagonally, providing bracing to the skeleton wall. The whole north face of the house with the exception of the first floor study with its Ned Kelly slit window was an emphatic diagram of structure through which the sun was invited to fill the house. The house, with its improbable and inadequate line of projecting shading battens, became a description of stress and support. However this was still not an entirely integrated window-wall despite the structural function of the diagonally glazed frame.

At the Troedel House, Wheeler's Hill (1953-54), Boyd adopted a more thermally sensible approach to a full-height wall of windows. Situated on a sloping site, the plan of the house was a facetted wedge, with a floor-to-ceiling window-wall stepping away from the edge of a terraced verandah that was in effect a double height solar pergola ("House at Wheelers Hill"). All the openable windows (which were also doors) on the facetted glazed wall were on the shorter return sections, while the major windows were fixed glass. Ventilation and vision were kept separate.

In both these houses, the artist's studio window that had once faced away from the sun was now turned towards it, inviting it in. Living was to be done in light. If painting, the act of representation, was to be achieved using reflected light, everyday living was to be undertaken in the full blaze of sunlight.

\section{The Stegbar 'Windowall'}

In 1953, Boyd achieved his goal of combining window and wall. That year, the Stegbar 'Windowall' was launched. The firm of Stegbar had been founded in Melbourne in 1946 by Brian Stegley (1920-1974) ('Steg-') and George Barrow ('-bar') with the intention of manufacturing clock cases and office furniture. In 1950 Stegbar began making timber windows from their factory on the corner of Bay and Aberdeen Roads in Sandringham. Designed by Robin Boyd, the Stegbar 'Windowall' system revolutionised the firm's economic base. By 1957, the firm had new and larger facilities in Rosalie Street, Springvale (also designed by Boyd) and offices in New South Wales and Queensland. In 1958, Stegbar opened offices in South Australia and the ACT.

In January 1956, Architecture and Arts ran a two page article on Stegbar's latest window design (16-17). The window-wall was defined as a structural window that stands the full height from floor to ceiling. The important and differentiating term was the word 'structural' which distinguished the window-wall from the non-structural curtain wall, the glazing system then finding favour in commercial and industrial applications across the globe, and being lionised by architectural commentators, especially examples like the use of Crittalls steel windows as a curtain wall - at Walter Gropius's Dessau Bauhaus (1925) and as a skin to the steel portal frames of Charles and Ray Eames's Case Study House in Pacific Palisades (1949).

While the overall appearance of the Stegbar 'Windowall' was light, the kiln-dried hardwood frames were strong enough to support any roof load likely to be placed on them in typical domestic construction. A key part of the 'Windowall's strength was that the individual framing members (5 1/2" x $13 / 4 "$ - 140mm x 45mm) were continuous in both directions - unbroken mullions and transoms - crossing each other in a copyright halved joint. In other words, it was like a floor to ceiling studio window.

The implication of the Stegbar 'Windowall' was that it was then possible to make all of the external walls of a house from such windowalls, with no additional supports required. The frames could carry a regular plastered ceiling, timber roof framing and terra cotta tiled roof. Stegbar 'Windowalls' were available in three standard series, but one could also custom-design a 'Windowall' with mullions and transoms in any desired positions, thus creating panes of any size of shape. The standard Stegbar 'Windowall' frame had mullions at 3 feet $(915 \mathrm{~mm})$ centres, thus the 'Windowall' was available in widths of any multiple of 3 feet.

The first of the three standard patterns was the 'SD' type, 8' 6" high $(2590 \mathrm{~mm}$, then the normal ceiling height in Australian domestic work) with a low transom at 2' 8" (812 mm) and another at 6' 8" (2032 mm). These heights matched the sill and door-head levels in other shorter windows of the same Stegbar 'S' series windows which might be used in ordinary solid walls elsewhere in the same building. The second pattern, the 'W' series, was 8' 6 3/4" (2610 mm) high, and the lower transom was dropped so that the high and low panes were the same size (26 1/2" [673 $\mathrm{mm}]$ ) and the central pane was 45" (1143 mm) clear. The third pattern was the ' $N$ ' series, with two evenly spaced transoms, but only 7' $03 / 4 "$ (2153 mm) high overall, and used mainly where boxed eaves caused the dropping of the window-head. 
A key aspect of Boyd's design was that he had deployed the timber stud frame as a selfcontained structural device. He had removed every second stud and instead of noggings and diagonal bracing, the continuous horizontal transoms gave the frame its lateral stability and strength. The implication was that the walls could be prefabricated off-site and that the specialist skills (and hence fees) of the window-joiner could be dispensed with. Another aspect of Boyd's window-wall was its division into other elements. The division of the frame respected the idea of the conventional door, and also the balustrade or chair rail. While the intention was to double the function of structure and glazing, the divisions of the frame meant that conventional relationships to the body and to other orthodox elements of architecture were in large part retained.

While other Australian architects like Douglas Snelling, Neville Gruzman, Harry Seidler and Peter Muller were able with handsome budgets to provide huge sheets of plate glass, to make their walls completely disappear and achieve complete transparency, the 'Windowall' through the pragmatics of its making, respected the divisions of scale that one would normally associate with the conventions of the orthodox window-opening and its frame. Indeed it is clear that across a range of domestic designs, Boyd enjoyed the qualities of the frame as an ordering device - as a screen - not as an element that one made disappear. His second house for his family in Walsh Street, South Yarra (1957) was another meditation on the artist's studio/living space volume and accompanying studio-window, but achieved through the expression of a rustic frame and with lead divisions between each glass panel. It was as if Boyd didn't want to relinquish the qualities of human scale implied by the frame, a tacit recognition of the smallscale units that made up the whole, units which could be economically supplied and assembled by hand. It was as Joan Ockman has acutely observed an example where "Modernism, as now reinterpreted largely meant a frame with repetitive components. Flexibility became interchangeability as the 'modular plan' replaced the free plan and 'form followed form' '(18). Yet despite its implications for mechanized production, Boyd's application of the frame was one that acknowledged the humanised process of making.

\section{Influence and Application}

The significance of Boyd's timber windowall was not that he invented the idea, nor that he was the only one to think of the idea. Indeed in Geoffrey Baker's 1948 book, Windows in Modern Architecture, there was a separate section on the window-wall described as "an attempt to bring the benefits of standardization and pre-cutting to the sort of window wall which many designers now want" (37). Several examples of timber window-walls were illustrated like Gardner Dailey's Owens House, Sausalito, 1939, Wurster Bernardi \& Emmons's Schuckl Canning Co. Building, Sunnyvale, California, 1942, and Franklin, Kump \& Falk's Elementary School, Fowler, California, 1938, all examples well known to Australian architects.

What was significant about Boyd's invention for Stegbar was that it was a structural windowwall. It was different from Chicago architect George Fred Keck's use of the modular but nonstructural Thermopane windows in his 'solar house' designs during the 1940s like the largely prefabricated Green's Ready-Built house, Rockford, Illinois, 1945 (Boyce). It was a different concept from the generously glazed designs of Northern Californian project house builders, Eichler Homes whose houses between 1949 and 1967 almost without exception adopted the structural post and beam redwood frame with plate glass infills (Adamson and Arbunich; Ditto, Wax, and Stern).

The importance of the Stegbar 'Windowall' was that it was manufactured, mass-produced and marketed by industry and adopted nationally, and that it was used by architects and speculative builders. Instead of having influence through type, plan or form, Boyd influenced an entire generation not just of architects, but builders and homemakers. One of Boyd's immediate applications of the Stegbar 'Windowall' on a broad scale was his 1955 design for the Peninsula House, a project home developed by Contemporary Homes Industries (CHI) and whose north face was constructed completely as a Stegbar 'Windowall'. Importantly, the 'Windowall' was adopted by other project house builders like the Sydney firm Sunline Homes, which was later to become the extremely influential and successful firm of Pettit and Sevitt in 1960 (Temple). In 1965 Merchant Builders in Melbourne also adopted the Stegbar 'Windowall', and by this time it was available in Western Red Cedar. In the work of other architects, the Stegbar 'Windowall' became the main feature of Neil Clerehan's Age Dream Home (1955), a public demonstration house. Clerehan, in his own home in Fawkner Street, South Yarra (1957-59) deployed the 'Windowall' as a two-storey self-supporting curtain wall, complete with double-height terylene curtains. 


\section{Return to the studio}

Stegbar as a company went from strength to strength. In 1963, Stegbar added aluminium windows to their market offerings. They had grown to a staff of 400 and the firm was floated as a public company. It was acquired in 1971 by F\&T Industries and in 1981, Stegbar was in turn acquired by ACI Australia Limited. Boyd, over the years, had retained a financial interest in the company, collected royalties from his original patent, and continued to experiment with his walls of windows. At the same time the project house market boomed in the late 1960s and his invention changed the look of Australia's suburban homes.

One Boyd design, though, stands out in this period. In many respects, it represents the turning of a full circle to his design research on the window-wall. In 1968, the Featherston-Currey house on The Boulevarde in Ivanhoe was completed. Designed for industrial designers Grant and Mary Featherston, this was Boyd's ideal house ("House, The Boulevarde, Ivanhoe, Victoria", Boyd and Strizic). It not only realised the fanciful and utopian idea of living on platforms in a garden but it was also a living and working environment for the ultimate ideal metropolitan couple. The Featherstons lived in a giant single studio/dining/living space. It was the ultimate warehouse/loft - the artist's studio - and, as had occurred at the studio of Maison Ozenfant, it had an illuminated ceiling, though not of glass but a quilt of Dacron fibreglass. But this time the studio-living room properly faced south, and instead of a custom-designed studio window, the Featherston house had a giant Stegbar 'Windowall'. The pre-cut frame of the everyday living room had returned to its studio roots.

\section{References}

Adamson, Paul and Arbunich, Marty. "Modern Technology ad the Middle-Class House." Eichler: modernism rebuilds the American dream. Layton, Utah: Gibbs Smith, 2002: 82-121.

Architecture and Arts (January 1956), "'Stegbar Windowalls': Here are Prefab Walls to Your Own Design."

Baker, Geoffrey. Windows in modern architecture. New York: Architectural Book Publishing Co., 1948.

Banham, Reyner. "Progressive Building in Paris: 1918-1928." Theory and Design in the First Machine Age. New York: Frederick A Praeger Inc., 1960: 217-219, 221-222.

Boyce, Robert. Keck and Keck. New York: Princeton Architectural Press, 1993.

Boyd, Robin. "Easy Building." The Age (21 September 1949).

Boyd, Robin and Strizic, Mark. Living in Australia. Sydney: Pergamon, 1970: 27, 48-53, 86-87, 114-115.

Clerehan, Neil. "The Age RVIA Small Homes Service." Transition 38 (1992).

Colquhoun, Alan. "Displacement of Concepts in Le Corbusier. "Essays in Architectural Criticism: Modern Architecture and Historical Change. Cambridge, Mass.: MIT Press, 1986 (1981): 5166.

Ditto, Jerry, Wax, Marvin and Stern, Lanning. Eichler homes: design for living. San Francisco: Chronicle Books, 1995.

Etchells, Frederick. 1927 English translation of Le Corbusier's Towards a New Architecture (Vers une Architecture [1922]).

Frampton, Kenneth. Le Corbusier. London: Thames \& Hudson, 2001.

Goad, Philip. The RVIA Small Homes Service 1947-1961. B.Arch. Research Report, Department of Architecture and Building, University of Melbourne, 1984.

Goad, Philip and Willis, Julie. "Invention from War: a circumstantial modernism for Australian architecture." The Journal of Architecture 8: 1 (Spring 2003): 41-62.

"House at Camberwell." Architecture and Arts (August 1954): 28-31.

"House at Wheeler's Hill." Architecture and Arts (August 1955): 22-24.

"House near Melbourne." The Architectural Review 108: 647 (November 1950): 315-316.

"House, The Boulevarde, Ivanhoe, Victoria." Architecture in Australia. 60:1 (February 1971): 5257. 
"House with a Skillion Roof." Australian Home Beautiful (March 1939): 12.

Ockman, Joan. "Introduction." Architecture Culture 1943-1968: A Documentary Anthology. New York: Columbia Books of Architecture/Rizzoli, 1993.

Serenyi, Peter. "Le Corbusier, Fourier and the Monastery of Ema." The Art Bulletin 49 (1967): 277-286 (reprinted in Serenyi, Peter, ed. Le Corbusier in Perspective. Englewood Cliffs, New Jersey: Prentice Hall Inc., 1972: 103-116.

Temple, Jeffrey. Pettit + Sevitt: the significance of Pettit and Sevitt Project Houses. B.Arch. dissertation, University of New South Wales, 1987.

"The Life and Good Works of Robin Boyd." Architecture and Arts (August 1954):19-23.

The Sun News Pictorial. The Sun Post-war Homes Competition. Melbourne, 1945. 